\title{
Voimakasaromisen sipulin pakkaskuivaus
}

\author{
YrJö Mälkki ja Sauli Heinonen \\ Valtion teknillinen tutkimuskeskus, Elintarvikelaboratorio, 02150 Espoo 15
}

\section{Freeze-drying of high aroma onions}

\author{
YrJö MÄLKKI and SAuli Heinonen \\ Food Research Laboratory, The Technical Research Centre of Finland, SF-02150 Espoo 15
}

\begin{abstract}
Pilot-plant freeze-drying experiments were performed using both vegetatively and seed-bred onions of Finnish origin. The strength of aroma was estimated by determining the pyruvic acid .ormed after crushing the tissue, and by determining the odour threshold values of onion suspensions. An inverse correlation was found between the logarithm of the threshold value and the pyruvic acid content, but due to the great variation both of these methods were used to obtain a more reliable information. In some cases, thé organoleptic profile and scoring methods were also used.

A short pre-drying at $28^{\circ} \mathrm{C}$ increased the pyruvic acid content of the vegetativelybred variety Lemi by $18 \%$. Storage at $-1^{\circ} \mathrm{C}$ also increased the pyruvic acid content; after 5 months it reached the maximum being $40 \%$ above the start value.

Both types of varieties were found suitable for freeze-drying. At a loading of $8 \mathrm{~kg} / \mathrm{m}^{2}$ the minimum length of the drying cycle was 6 hours, when the final moisture level was $3.5 \%$. Slowly frozen $\left(-20^{\circ} \mathrm{C}\right.$, air velocity $\left.2.3 \mathrm{~m} / \mathrm{s}\right)$ samples had a lower shrinkage during drying, and a better organoleptic quality. According to electron micrographs, the reason was supposed to be a formation of channels through the tissue enhancing the mass transfer.

According to all the evaluation methods used, the aroma of the freeze-dried Finnish onions was fairly rich compared to the literature data and to commercial samples studied, presumed, however, that the diminution before drying was done without crushing the tissue. According to the flavour profile determinations, the typical pungent and lachrymatory factors were strong in the Finnish onions.

The retention of pyruvic acid during freeze-drying was as a mean for vegetatively bred onions $90 \%$, and for the seed-bred onions $70 \%$. The difference is evidently due to the higher content of soluble carbohydrates in the former. The threshold values of freeze-dried, vegetatively bred varieties were between $1.2 \ldots 2.7 \mathrm{mg}$ dry matter/1000 $\mathrm{ml}$, for seed-bred varieties between $0.4 \ldots 0.7 \mathrm{mg} / 1000 \mathrm{ml}$, respectively. Corresponding literature data vary between $2.5 \ldots 40 \mathrm{mg} / 1000 \mathrm{ml}$. The formation of pyruvic acid was for both groups about $45 \mu \mathrm{mol} / \mathrm{g}$ dry matter. The high dry matter of the vegetatively bred varieties offers economical advantages for freeze-drying.
\end{abstract}

Sipulin kulutuksessa on viimeisen kahden vuosikymmenen aikana tapahtunut jatkuvaa siirtymistä tuoreen sipulin käytöstä puolivalmisteiden tai teollisten valmisteiden käyttöön. Tätä kehitystä on tapahtunut sekä teollisuudessa ja suurtalouksissa että kotitalouksissa. Tärkeimpinä syinä ovat olleet 
työn rationalisointi, säilyvyys ja hygieeniset seikat. Freemanin ja Whenhamin tutkimuksissa (1974) on vertailtu etikkasäilöttyjen, lämpösäilöttyjen, keitettyjen friteerattujen, pakastettujen, kuumailmakuivattujen ja pakkaskuivattujen sipulivalmisteiden aromia, ja todettu pakkaskuivauksen antavan aromiltaan ylivoimaisesti parhaat valmisteet.

Kotimaista sipulia on tunnetusti pidetty voimakasaromisena. Tämä on todettu myös kemiallisten tunnuslukujen perusteella (МäLKKI ym., 1978). Myös sen korkea kuiva-aine- ja disakkaridipitoisuus ovat edullisia kuivausprosessin kannalta. Tämän tutkimuksen tarkoituksena on ollut selvittää tämän raaka-aineen pakkaskuivauksen optimaalisia olosuhteita ja saatujen valmisteiden laatua markkinoilla oleviin valmisteisiin verrattuna.

\section{Aineisto ja menetelmät}

\section{Sipulimateriaali}

Vuoden 1973 ja 1974 kokeissa käytetty ryvässipuli Lemi sekä vuoden 1973 esikokeissa käytetty pistosipuli Stuttgarter Liva hankittiin Kesko Oy:n LänsiHahkialan koetilalta Hauholta ja se toimitettiin suoraan pellolta laboratorioon. Vuoden 1974 kokeissa käytetty riihikuiva pistosipuli oli tuntematonta lajiketta ja peräisin Saarijärven Vihannes Oy:Itä Saarijärveltä. Kuivauskokeissa käytettiin vain yli 50 gramman painoisia sipuleita.

\section{Pakkaskuivauksen suoritus}

Sipulit kuorittiin käsin ja viipaloitiin terävällä leikkurilla kohtisuoraan pituusakselia vastaan. Ne jäädytettiin välittömästi Fricoscandia Pilot Freezer pakastimessa käyttäen vaakasuoraa ilmavirtausta ja kahta eri jäädytysnopeutta. Nopeammassa jäädytyksessä oli ilman lämpötila $-40^{\circ} \mathrm{C}$ ja nopeus $4,6 \mathrm{~m} / \mathrm{s}$ ja hitaammassa vastaavasti $-20^{\circ} \mathrm{C}$ ja $2,3 \mathrm{~m} / \mathrm{s}$. Pakkaskuivaaja oli Atlas Pilot Plant Freeze-Drying Unit Ray 1, jossa lämmönsiirto tapahtuu lähinnä säteilemällä, koska lämmityselementit eivät ole kosketuksissa tuotteeseen.

Kuivauksen aikana rekisteröitiin lämmityselementin ja kuivattavan tuotteen lämpötilat sekä kuivauskammion paine ja tuotteen painonväheneminen.

Kuivausta säädeltiin lämmitysteholla ja kuivaustilan paineella. Kuivauksen päätyttyä laskettiin kuivauskammioon kuivaa typpeä ja kuivasipulit pakattiin typpiatmosfääriin lasitölkkeihin.

\section{Analyysimenetelmät}

Aromin voimakkuutta tutkittiin määrittämällä kemiallisesti palorypälehappo $\mathrm{P}_{\mathrm{T}}$, jota syntyy kudosta murskattaessa käynnistyvässä entsymaattisessa arominmuodostusreaktiossa ekvimolaarisesti hajonneen aromiprekursorin määrään nähden. Lisäksi tutkittiin eräissä tapauksissa määrityksen aikana syntyvän palorypälehapon osuutta $\mathrm{P}_{\mathrm{E}}$ vähentämällä kokonaismäärästä kontrollinäytteistä saatu palorypälehappomäärä $P_{C}$. Kontrollinäytteiden entsyymit inaktivoitiin käsittelemällä näytteitä mikroaaltouunissa $(2450 \mathrm{MHz}) 5 \mathrm{minuu}-$ tin ajan. 
Koska sipulin aromi on hyvin voimakas, käytettiin aistivaraisessa arvostelussa lähinnä hajun kynnysarvomenetelmää. Menetelmässä lietetään sipulia veteen ja määritetään minimikonsentraatio, jossa sipulin haju on tunnettavissa. Lisäksi käytettiin eräissä tapauksissa aistinvaraisen arvostelun arvopiste- ja profiilimenetelmiä.

Aromianalyysiä varten punnittiin kolmen sipuliyksilön syötävästä osasta yhteensä noin 10 gramman näyte tai noin $\mathbf{5}$ grammaa kuivasipulia, lisättiin $100 \mathrm{ml}$ tislattua vettä, imeytettiin 10 minuuttia ja homogenisoitiin Virtis homogenisaattorilla. Suspension annettiin seistä 1 tunti, jonka jälkeen tilavuus täytettiin $200 \mathrm{ml}$ ksi ja suspensio suodatettiin Büchnersuodattimella käyttäen imua. Suodoksesta tehtiin sopivat laimennokset ja sitä käytettiin palorypälehappo- ja kynnysarvomäärityksiin.

Palorypälehappomääritys tehtiin Schwimmerin ja Westonin (1961) mukaan neljästä eri laimennoksesta ja keskiarvo laskettiin kolmesta laimennoksesta, jotka osuivat sopivalle konsentraatioalueelle.

Kynnysarvomääritys tehtiin Schwimmerin ja GUAdagnin (1962) mukaan sillä erotuksella, että duo-trio testin sijasta käytettiin paritestiä. Kynnysarvo oli se konsentraatio, jonka $70 \%$ arvostelijoista tunnisti sipulin hajun perusteella. Arvostelijoina oli harjaantunut 12 henkilön ryhmä ja jokainen näyte arvosteltiin kahdesti.

Sipulin makuprofiilia määritettäessä pureskeltiin kuivasipulinäytettä 30 sekuntia. Jokainen esiintuleva maku pyrittiin tunnistamaan ja kunkin maun voimakkuus arvioitiin havaitsemisjärjestyksessä asteikolla $0-4$, jolla 1 oli heikoin ja 4 voimakkain aistimus. Arvosteluun osallistui 6 makuarvosteluun harjaantunutta henkilöä.

Tuoreen sipulin vesipitoisuus määritettiin kuivaamalla noin 3 gramman suuruista näytettä 6 tuntia $103^{\circ} \mathrm{C}$ :ssa. Kuivasipulin vesipitoisuus määritettiin Karl-Fischer titrauksella McСomBin ja WRIGHTin (1954) mukaan ja näyte otettiin 16 grammasta viljanäytemyllyllä (JACOBSEN, 1975) jauhettua kuivasipulia. Koska vesi on kuivavihanneksissa vahvasti sitoutuneena, käytettiin uuttamiseen formamidia. Veden aktiivisuus kuivasipulissa määritettiin Hygrodynamics Inc'n mittauslaitteella.

Kuivasipulin ominaistilavuus, jota käytettiin kutistumisen laskemiseen määritettiin käyttämällä mitta-asteikolla varustettua astiaa ja siemeniä.

Kuivasipulin väri määritettiin HeNDELin ja BAILYn (1950) mukaan ekstraktin absorbanssina.

Veden uudelleenimeytymistä tutkittiin imeyttämällä kuivasipulia 5 ja 40 minnuttia $23^{\circ}$ C:ssa vedessä (Hernonen, 1974).

\section{Tulokset}

\section{Sipulin esikuivaus ja kylmävarastointi}

MÄLKIN ym. (1978) tulosten perusteella valittiin ryvässipuli Lemi ja pistosipuli Stuttgarter Liva esikokeisiin syksyllä 1973. Esikokeiden perusteella valitiin ryvässipuli Lemi, koska sille saatiin suurempi palorypälehappomäärä sekä tuorepainoa että kuiva-ainetta kohti. Ryvässipulin kuiva-ainepitoisuus oli myös korkeampi. Sipuli korjattiin normaaliin aikaan ja siirrettiin tuuletet- 
tuun huoneeseen $+28^{\circ}$ C:een lämpötilaan, koska lyhyen esikuivauksen oli havaittu lisäävän palorypälehapon muodostusta sekä MÄLKıN ym. (1978) tutkimuksissa että esikokeissa. Palorypälehapon muodostus lisääntyi kolmen vuorokauden pituisen esikuivauksen aikana $17 \%$. Esikuivauksen jälkeen sipulit siirrettiin pakkasarkkuun noin $0^{\circ} \mathrm{C}$ :een lämpötilaan. Sipulien jäähdyttämistä ei voitu suorittaa kovin nopeasti jäätymisvaaran takia ja se oli ilmeisesti syynä siihen, että esikuivauksen optimiaika ylitettiin ja palorypälehapon muodostus väheni jälleen. Pakkasarkun olosuhteet $-1 \ldots+3^{\circ} \mathrm{C}: n$ lämpötila ja $70 \ldots 90 \%$ suhteellinen kosteus olivat sipulin varastoinnille suotuisat ja palorypälehapon muodostus lisääntyi huomattavasti varastoinnin kuluessa. Viiden kuukauden kuluttua oli pitoisuus $40 \%$ alkuperäistä korkeammalla tasolla. Palorypälehapon muodostuksen muutokset esikuivauksen ja varastoinnin aikana on esitetty kuvassa 1. Esikuivauksen edullinen vaikutus oli havaittavissa myös vuoden 1974 kuivauskokeissa, jolloin ryvässipuli Lemin palorypälehappopitoisuus kasvoi $19 \%$ ja pysyi tällä tasolla ilmeisesti siksi, että sipulit siirrettiin kylmävarastoon jo 2,5:n vuorokauden esikuivauksen jälkeen. Pistosipulilla vuonna 1973 suoritetuissa esikokeissa ei havaittu esikuivauksen lisäävän palorypälehapon muodostusta ja vuoden 1974 kokeissa ei asiaa voitu tutkia, koska käytetty pistosipuli oli riihikuivaa.

Esikuivauksesta aiheutuva painotappio vaihteli välillä $5 \ldots 10 \%$. Kuivaainetappio oli ryvässipulilla noin $1 \%$ ja pistosipulilla esikokeissa 2,5\%.

Ryvässipuli oli käyttökelpoista pakkaskuivaukseen koko koesarjan ajan eli yli 5 kuukautta, jos ei oteta huomioon mikrobiologista pilaantumista. Pistosipulilla havaittiin pakkaskuivausta haittaavaa silmujen kasvua vasta $6 \ldots 7$ kuukauden kylmävarastoinnin jälkeen.

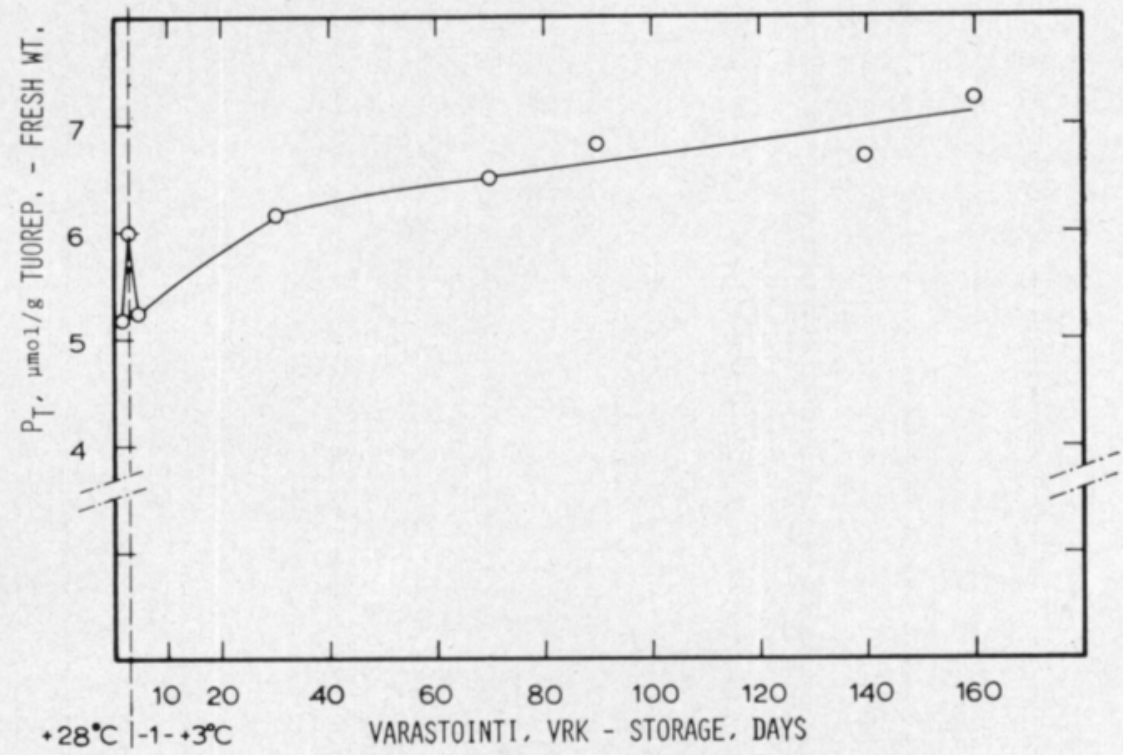

Kuva 1. Esikuivauksen ja kylmävarastoinnin vaikutus ryvässipuli Lemin palorypälehaponmuodostukseen $\left(\mathrm{P}_{\mathrm{T}}\right)$.

Fig. 1. Effect of pre-drying and refrigerated storage on pyruvic acid formation $\left(P_{T}\right)$ of a vegatatively bred variety Lemi 


\section{Pakkaskuivauksen optimonti}

Sipulille edullisten pakkaskuivausolosuhteiden selvittämiseksi tutkittiin vuoden 1973 kokeissa seuraavien tekijöiden vaikutusta.

Kuivaussyklin muoto ja kuivauksen loppukohta

Kuormitus (kerrospaksuus)

Sipulin jääfaasin ja kuivan kerroksen lämpötilat kuivauksen aikana

Jäädytysnopeus

Kuivauskammion paine

Tulokset on esitetty yksityiskohtaisesti muualla (HEINONEn, 1974) ja seuraavassa on yhteenveto tärkeimmistä tuloksista.

Edulliseksi kuormitukseksi havaittiin noin $8 \mathrm{~kg} / \mathrm{m}^{2}$, koska suuremmilla kuormituksilla kuivaus oli hidas ja tuote epähomogeeninen. Koska jään nopea sublimoituminen jäähdyttää voimakkaasti tuotetta, voitiin kuivauksen alussa käyttää suurta lämmitystehoa, jolloin lämmityselementin lämpötila oli yli $200^{\circ}$ C. Kuivauksen edistyessä vähennettiin lämmitystehoa siten, että tuotteen pintakerros ei ruskistunut. Jääfaasin ja kuivan kerroksen lämpötilat tuotteessa pysyivät likimain vakioina sublimointivaiheen ajan. Jään lämpötila tuotekerroksen keskellä oli keskimäärin $-22^{\circ} \mathrm{C}$ ja sublimoitumisrintamassa noin $-10^{\circ} \mathrm{C}$ koeajossa, jossa saatiin edullinen kuivausajan ja valmisteen laadun suhde. Kuivasipulin säilyvyyden kannalta oli vaatimuksena alle $4 \%$ :n vesipitoisuus (HEIss, 1968). Tähän päästiin pitämällä tuotteen lämpötila desorptiovaiheessa $+50^{\circ} \mathrm{C}$ :ssa. Jos lämpötilaa nostettiin niin paljon, että kuivausaika lyheni olennaisesti, oli valmiste palaneen makuinen. Edellä esitetyissä olosuhteissa oli kuivausaika noin 6 tuntia, joka teollisessa valmistuksessa antaa mahdollisuuden kolmeen sykliin vuorokaudessa, koska on otettava huomioon mm. täyttö- ja tyhjennysajat. Kuivasipulin vesipitoisuus oli keskimäärin $3,5 \%$ ja veden aktiivisuus sipulissa vaihteli välillä $0,05 \ldots 0,13$.

$53 \mathrm{~Pa}(0,4 \mathrm{~mm} \mathrm{Hg})$ osoittautui edulliseksi kuivauskammion paineeksi. Jos paine nostettiin arvoon $133 \mathrm{~Pa}(1,0 \mathrm{~mm} \mathrm{Hg})$, nousivat jääfaasin lämpötilat $2 \ldots 6^{\circ} \mathrm{C}$. Havaitulla vähäisellä kuivausnopeuden kasvulla ei ollut käytännön merkitystä ja alempi paine oli edullisempi valmisteen laadun kannalta. Käytettäessä ennen kuivausta hitaampaa jäädytystä saavutettiin hieman nopeampi loppukuivaus kuin nopeammin jäädytetyllä tuotteella. Kuvasta 2 nähdään, että hitaammin jäädytetty sipuli kutistui selvästi vähemmän kuivauksen aikana. Elektronimikroskooppitutkimuksen perusteella näyttää todennäköiseltä syyltä tähän se, että hitaan jäädytyksen aikana syntyi riittävästi solunseinämien läpi kulkevia kiteitä ja siten myös kuivauksen edistyessä vastaavia kanavia, jotka helpottivat kuivausta. Tällöin kutistuminen ja tuotteen muu vaurioituminen oli kuivauksen aikana vähäisempää. Tämä tulos oli huomionarvoinen ja jonkin verran yllättävä, koska nopea jäädytys on todettu useimmiten edulliseksi pakkaskuivatun valmisteen laadun kannalta.

\section{Pakkaskuivattujen valmisteiden aromi}

Kuvassa 3 on esitetty kotimaisten tuoreiden ja pakkaskuivattujen sipuleiden aromi määritettynä palorypälehaponmuodostuksena $\mathrm{P}_{\mathrm{T}}$ sekä hajun kynnysarvona. Kuvassa on lisäksi kaupallisille ulkolaisille sipulivalmisteille 

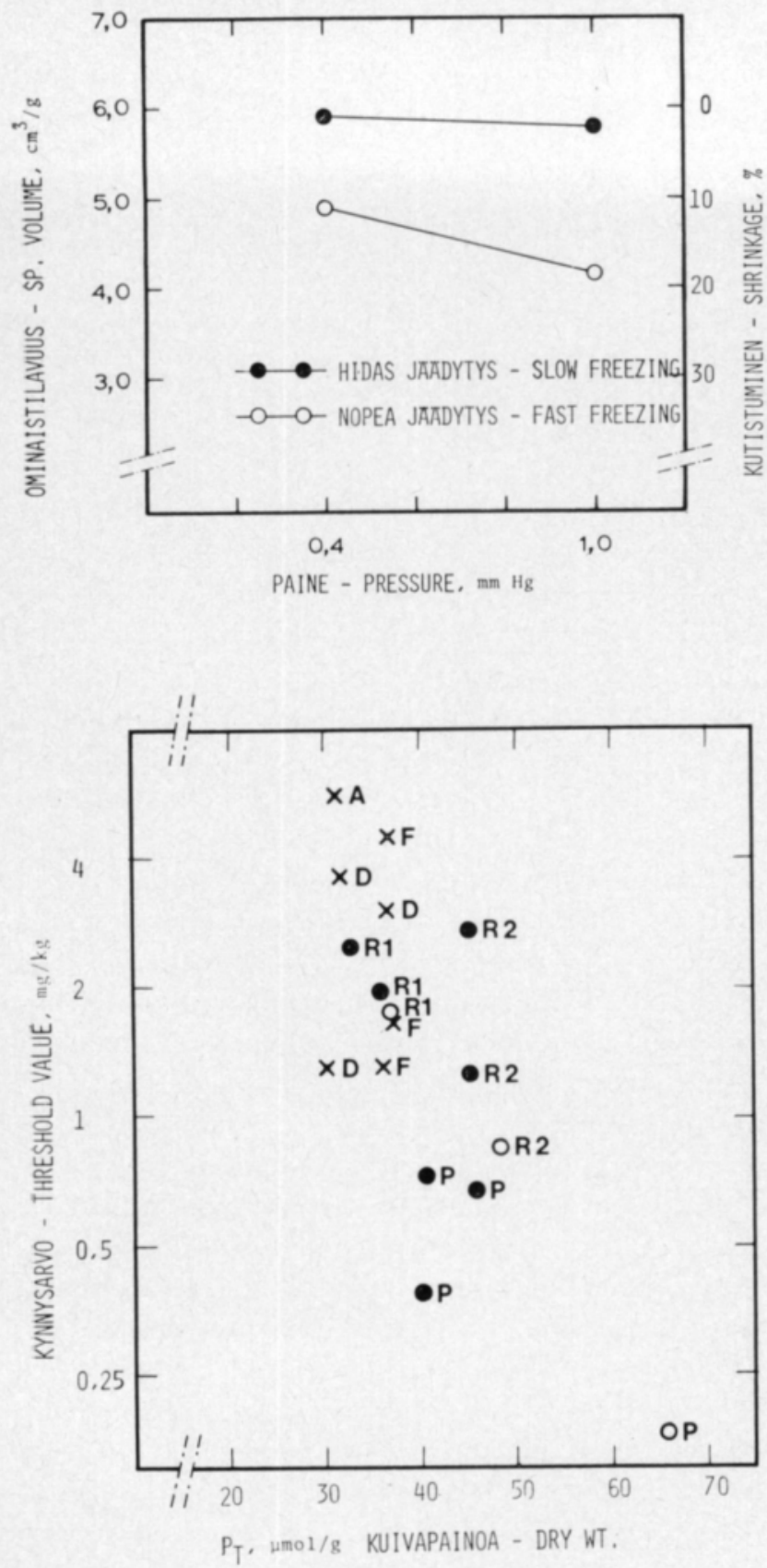

Kuva 2. Jäädytysnopeuden ja kuivauskammion paineen va!kutus sipulin kutistumiseen. Fig. 2. Effect of freezing rate and chamber pressure on the shrinkage of onions.

Kuva 3. Hajun kynnysarvon ja palorypälehaponmuodostuksen $\left(\mathrm{P}_{\mathrm{T}}\right)$ välinen riippuvuus. Fig. 3. The correlation of odour threshold values and formation of pyruvic acid $\left(P_{T}\right)$.

Merkinnät - Symbols: o tuore - fresh, - pakkaskuivattu freeze-dried, P pistosipuli seed-bred, R 1 ryvässipuli 1973 - vegetetively bred 1973, R 2 ryvässipuli 1974 - vegetatively bred 1974, xD tanskalainen pakkaskuivattu - Danish freezedried, $\mathrm{xF}$ ranskalainen pakkaskuivattu - French freeze-dried, xA ilmakuivattu - hot-air dried.

saatuja määritystuloksia. Palorypälehapon muodostuksen ja kynnysarvon välillä on suuresta hajonnasta huolimatta havaittavissa käänteistä riippuvuutta. Riippuvuus on jonkin verran selvempi, jos käytetään kynnysarvon logaritmia, kuten Schwimmer ym. (1964) ovat esittäneet. Molempien menetelmien käyttäminen rinnan antoi huomattavasti luotettavamman kuvan aromin voimakkuudesta kuin jompikumpi yksin. Aistinvarainen kynnysarvomentelmä on tosin huomattavan työläs ja virheherkkä. Kuvassa 3 nähdään myös, että vuo- 
Taulukko 1. Tuoreen ja pakkaskuivatun sipulin aromin voimakkuus.

Table 1. Flavour strexgth of fresh and freeze-dried onion.

\begin{tabular}{|c|c|c|c|}
\hline $\begin{array}{l}\text { Näyte } \\
\text { Sample }\end{array}$ & $\begin{array}{c}\text { Palor.h. - Pyruv.acid } \\
\mu \mathrm{mol} / \mathrm{g} \text { kuiva-ain. } \\
\mu \mathrm{mol} / \mathrm{g} \text { dry } w t .\end{array}$ & $\begin{array}{c}\text { Kynnysarvo, } \\
\text { mg kuiva-ain. } / 1000 \mathrm{ml} \\
\text { Odour threshold, } \\
\text { mg dry matter } / 1000 \mathrm{ml}\end{array}$ & $\begin{array}{l}\text { Hajupisteet, } 0-4 \\
\text { Odour score, } 0-4\end{array}$ \\
\hline $\begin{array}{l}\text { Tuore sipuli } \ldots \ldots \ldots \ldots \ldots \ldots \ldots \\
\text { Fresh onion }\end{array}$ & 37.1 & 1.76 & - \\
\hline $\begin{array}{l}\text { Pakkaskuivattu sipuli } \\
\text { Freeze-dried onion }\end{array}$ & & & \\
\hline $\begin{array}{l}\text { hidas jäähdytys ................ } \\
\text { slow freezing }\end{array}$ & 35.4 & 1.25 & 3.9 \\
\hline $\begin{array}{l}\text { nopea jäädytys } . . . \cdots \ldots \ldots . . . \\
\text { fast freezing }\end{array}$ & 32.3 & 2.45 & 2.8 \\
\hline $\begin{array}{l}\text { ulkom. valmiste ............... } \\
\text { foreign commercial sample }\end{array}$ & 36.8 & 3.00 & 2.7 \\
\hline
\end{tabular}

den 1974 sato oli ryvässipuli Lemillä selvästi aromirikkaampaa kuin edellisen vuoden sato.

Taulukossa 1 on vertailtu vuoden 1973 ryvässipuli Lemin, siitä kuivattujen valmisteiden ja ulkomaisen pakkaskuivatun valmisteen aromia eri menetelmien tulosten perusteella. Kuvassa 4 on lisäksi esitetty kuivavalmisteiden makuprofiilit.

Kaikkien menetelmien tulokset osoittavat kotimaisesta sipulista pakkaskuivatun valmisteen olevan varsin aromirikkaan, ja makuprofiilien perusteella havaittiin sipulille luonteenomaiset kirpeät ja pistävät maut voimakkaina myös kuivavalmisteissa. Ero kaupalliseen ulkomaiseen valmisteeseen oli voimakkain juuri näissä ominaisuuksissa (kuva 4).

Käytetty kemiallinen arominmääritysmenetelmä antaa tulokseksi määrityksen aikana eli sipulia murskattaessa tai kuivasipulia imeytettäessä syntyvän palorypälehapon määrän $\mathrm{P}_{\mathrm{E}}$ sekä sipulissa ennestään olevan palorypälehapon tai sen kaltaisesti reagoivien yhdisteiden yhteismäärän $\mathrm{P}_{\mathrm{T}}$. On kuitenkin mahdollista, että arominmuodostusreaktio pääsee tapahtumaan jo sipulin prosessoinnin aikana ja osa aromitekijöistä menetetään taikka syntyy määritystä häiritseviä yhdisteitä. Taulukossa 2 on esitetty määrityksen aikana syntyneen palorypälehapon osuus vuoden 1974 sadon ryvässipuli Lemillä ja siitä kuivatuilla valmisteilla. Tuloksista havaitaan, että määrityksen aikana syntyneen palorypälehapon osuus oli suuri myös pakkaskuivatuilla valmisteilla.

Partikkelikoon vaikutus viipaloinnin ja pakkaskuivauksen aikana tapahtuneisiin aromitappioihin on esitetty taulukossa 3 , jossa on vertailtu eri tavalla viipaloituja pistosipulivalmisteita.

Taulukossa 4 on vertailtu vuoden 1974 sadon ryväs- ja pistosipulia ja niistä pakkaskuivattuja valmisteita.

Tuoreen sipulin palorypälehappomäärissä ei ryväs- ja pistosipulilla ollut suuriakaan eroja. Pistosipulin alhaisemmasta kuiva-ainepitoisuudesta johtuen oli sen palorypälehappomäärä suurempi kuiva-ainetta kohti. Koska ryvässipulin palorypälehappotappiot olivat vähäisemmät pakkaskuivauksen aikana, 

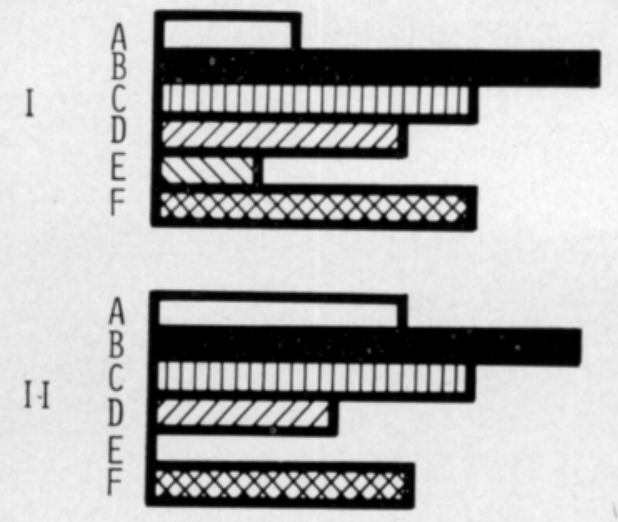

Kuva 4. Pakkaskuivattujen sipuleiden makuprofiilit.

Fig. 4. Flavour profiles of freeze-dried onions.

Näytteet - Samples: I hidas jäädytys - slow freezing, II nopea jäädytys - fast freezing, III: ulkomainen kaupallinen valmiste - foreign commercial sample. Maku- ja aromisävyt - Flavour profile notes: A makea - sweet, B kirpeä - pungent, C kyynelöitymistä aiheuttava - lachrymatory, D karvas - bitter, E pehmeä favourable flavour, F jälkimaku aftertaste.

Taulukko 2. Määrityksen aikana syntyneen palorypälehapon $\left(\mathrm{P}_{\mathbf{E}}\right)$ osuus kokonaismäärästä $\left(\mathrm{P}_{\mathrm{T}}\right)$ ryvässipulilla.

Table 2. Proportion of the pyruvic acid produced during analysis $\left(P_{E}\right)$ from the total pyruvic acid $\left(P_{T}\right)$ of the vegetatively bred onions.

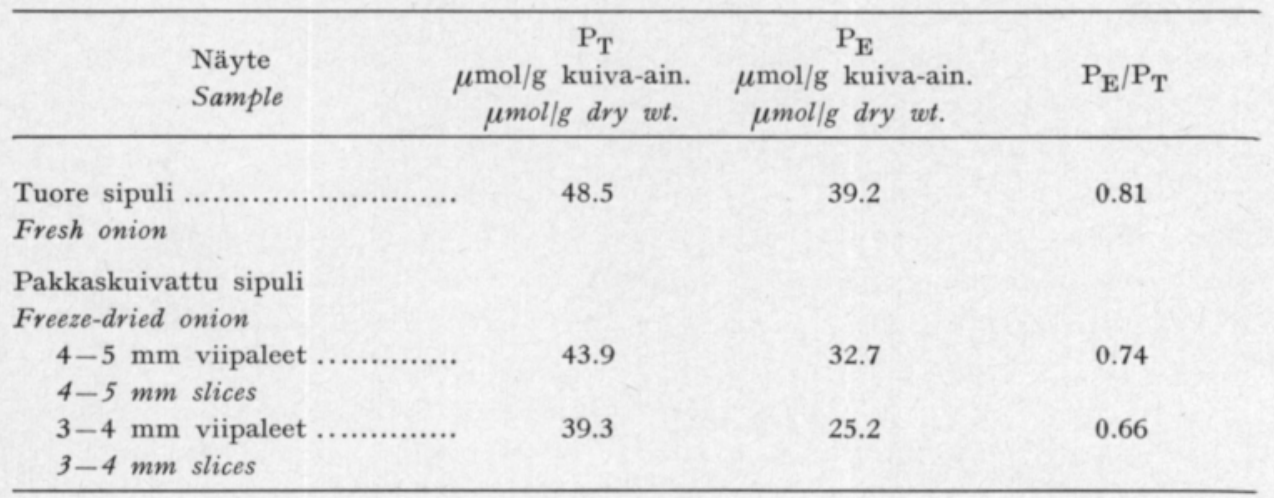

oli kuivavalmisteiden palorypälehappopitoisuus yhtä suuri. Pistosipulin hajun kynnysarvo oli jonkin verran pienempi kuin ryvässipulin, mutta sen merkitystä on vaikeata arvioida, koska lajikkeiden koostumus (MÄLKKI ym. 1978) ja tästä johtuen myös aromin profiili ovat erilaisia.

\section{Tulosten tarkastelua}

Palorypälehapon kokonaismäärä, $\mathrm{P}_{\mathrm{T}}$ ja aistinvaraisesti määritetty hajun kynnysarvo antoivat yhdessä melko hyvän kuvan aromin voimakkuudesta kun oli kyseessä tuore tai varovaista käsittelyä käyttäen pakkaskuivattu val- 
Taulukko 3. Viipaloinnin vaikutus pakkaskuivatun sipulin aromiin pistosipulilla.

Table 3. Influence of slicing on the flavour strength of freeze-dried seed-bred onion.

\begin{tabular}{|c|c|c|c|}
\hline $\begin{array}{l}\text { Näyte } \\
\text { Sample }\end{array}$ & $\begin{array}{c}\mathrm{P}_{\mathrm{T}} \\
\mu \text { mol/g kuiva-ain. } \\
\mu m o l / g \text { dry wt. }\end{array}$ & $\begin{array}{l}\mathrm{P}_{\mathrm{T}} \text {-retention, \% } \\
P_{T^{-} \text {-retention, } \%}\end{array}$ & $\begin{array}{c}\text { Kynnysarvo, } \\
\text { mg kuiva-ain. } / 1000 \mathrm{ml} \\
\text { Odour threshold, } \\
\text { mg dry matter } / 1000 \mathrm{ml}\end{array}$ \\
\hline $\begin{array}{l}\text { Tuore sipuli ....................................... } \\
\text { Fresh onion }\end{array}$ & 65.7 & - & 0.18 \\
\hline \multicolumn{4}{|l|}{$\begin{array}{l}\text { Pakkaskuivattu sipuli } \\
\text { Freeze-dried onion }\end{array}$} \\
\hline $\begin{array}{l}5-6 \mathrm{~mm} \text { viipaleet, erä } 1 \ldots \\
5-6 \mathrm{~mm} \text { slices, batch } 1\end{array}$ & 45.7 & $7 \mathrm{C}$ & 0.67 \\
\hline $\begin{array}{l}5-6 \mathrm{~mm} \text { viipaleet, erä } 2 \ldots \\
5-6 \mathrm{~mm} \text { slices, batch } 2\end{array}$ & 39.9 & 61 & 0.39 \\
\hline $\begin{array}{l}3-4 \mathrm{~mm} \text { viipaleet ......................... } \\
3-4 \mathrm{~mm} \text { slices }\end{array}$ & 34.6 & 53 & 0.56 \\
\hline $\begin{array}{l}3 \times 10 \times 10 \mathrm{~mm} \text { palat } \ldots \ldots . . \\
3 \times 10 \times 10 \mathrm{~mm} \text { pieces }\end{array}$ & 28.5 & 43 & 1.27 \\
\hline
\end{tabular}

Taulukko 4. Ryväs- ja pistosipuli vertailu

Table 4. Comparison of seed-bred and vegetatively bred onions

\begin{tabular}{llc}
\hline & \multicolumn{2}{c}{ Tyyppi } \\
Näyte & Type \\
Sample & Ryvässipuli & Pistosipuli \\
& Vegetatively & Seed-bred \\
bred onion & onion \\
\hline
\end{tabular}

Tuore sipuli

Fresh onion

kuiva-aine \%

dry matter \%

$\mathrm{P}_{\mathrm{T}}, \mu \mathrm{mol} / \mathrm{g}$ tuoreain.

$P_{T}, \mu$ mol/g fresh wt.

$\mathrm{P}_{\mathrm{T}}, \mu \mathrm{mol} / \mathrm{g}$ kuiva-ain.

$P_{T}, \mu \mathrm{mol} / \mathrm{g}$ dry $w t$.

Kynnysarvo, mg kuiva-ain./1000 ml

Odour threshold, mg dry matter/1000 ml

Pakkaskuivattu sipuli

Freeze-dried onion

$\mathrm{P}_{\mathbf{T}}, \mu \mathrm{mol} / \mathrm{g}$ kuiva-ain.

$P_{T}, \mu m o l / g$ dry $w t$.

$\mathrm{P}_{\mathbf{T}}$ retentio, \%

$P_{T}$ retention, \% 
Taulukko 5. Aromin voimakkuus eri tutkimuksissa palorypälehapon muodostuksen $\left(\mathrm{P}_{\mathrm{T}}\right)$ ja kynnysarvon perusteella.

Table 5. Aroma strength in various investigations as determined by the formation of pyruvic acid $\left(P_{T}\right)$ and by odour threshold

Kynnysarvo

Tutkijat - Authors

Näytteet - Samples

$\mathrm{P}_{\mathrm{T}} \mu \mathrm{mol} / \mathrm{g}$ $\mathrm{mg}$ kuiva-ain./1000 ml kuiva-ain. (dry wt) Odour thres hold mg dry matter $/ 1000 \mathrm{ml}$

\begin{tabular}{|c|c|c|c|}
\hline FrEEMAN et al. (1974) & tuore - fresh & $69.1 \ldots 145.4$ & $1.0 \ldots 1.75$ \\
\hline , & pakkaskuivattu - freeze-dried & $60.1 \ldots 91.7$ & 20 \\
\hline , & ilmakuivattu - air-dried & $23.9 \ldots 47.5$ & \\
\hline , & kaupallinen - commercial & $12.7 \ldots 30.5$ & \\
\hline SchWimmer et al. (1964) & tuore - fresh & $69.3 \ldots 156.1$ & $0.4 \ldots 3.3$ \\
\hline , & ilmakuivattu - air-dried & $18.6 \ldots 51.9$ & $2.5 \ldots 21.7$ \\
\hline PELEg et al. (1970) & ilmakuivattu - air-dried & $19.6 \ldots 39.2$ & $4.0 \ldots 38.1$ \\
\hline SAGUY et. al. (1970) & tuore - fresh & & $3.8 \ldots 21$ \\
\hline 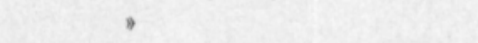 & ilmakuivattu - air-dried & & $13.0 \ldots 28.6$ \\
\hline MäLккі, NiккіLÃ \& Aalto (1978) & tuore - fresh & $56.9 \ldots 118.4$ & \\
\hline & pakkaskuivattu - freeze-dried & $34.8 \ldots 134.1$ & \\
\hline Tämä tutkimus - This study & tuore - fresh & $37.1 \ldots 65.7$ & $0.2 \ldots$ \\
\hline & pakkaskuivattu - freeze-dried & $35.4 \ldots 45.7$ & $0.4 \ldots 2.7$ \\
\hline
\end{tabular}

miste. Jos halutaan tutkia muiden prosessointimenetelmien taikka kuivasipulin varastoinnin vaikutusta aromiin, voi olla syytä käyttää myös muita menetelmiä mm. häiritsevien karbonyyliyhdisteiden tai sivuhajujen aiheuttamien virhemahdollisuuksien takia. (PELEG ym. 1970, SAGUY ym. 1970, Freeman ja Whenham, 1974, Tewari ja Bandyopadhyay, 1977).

Verrattaessa tämän tutkimuksen tuloksia ulkomaisiin tutkimuksiin (Taulukko 5) havaitaan, että käytetyn kotimaisen sipulimateriaalin palorypälehappopitoisuus ei ollut alunperin kovin korkea, mutta sensijaan tappiot pakkaskuivauksessa olivat suhteellisen vähäiset. Eri laboratorioissa kynnysarvomenetelmillä saadut tulokset eivät ilmeisestikään ole täysin vertailukelpoisia, mutta niistä käy kuitenkin selvästi ilmi, että kotimaisen sipulin hajun intensiteetti oli varsin voimakas myös pakkaskuivauksen jälkeen. Tätä johtopäätöstä tukevat myös makuprofiilikokeiden tulokset.

Kotimaisesta sipulimateriaalista todettiin sekä ryväs- että pistosipulin soveltuvan hyvin pakkaskuivauksen ja niistä pakkaskuivatut valmisteet olivat laadullisesti hyvin kilpailukykyisiä vastaaviin ulkomaisiin kaupallisiin valmisteisiin verrattuina. Ryvässipulin huomattavan korkea kuiva-aine $(17,5 \ldots$ $20 \%$ ) olisi ilmeisesti varsin merkittävä tekijä valmistuksen taloudellisuuden kannalta. Ryvässipulin palorypälehappopitoisuus ei ollut käytetyssä materiaalissa niin korkea kuin aikaisemmat tulokset (MäLKKI ym., 1978) antoivat aiheen odottaa. Sensijaan palorypälehappotappiot olivat pakkaskuivauksen aikana yleensä alle $10 \%$ eli erittäin vähäiset. Tähän ovat ilmeisesti vaikuttaneet ryvässipulin korkea kuiva-aine ja ennenkaikkea korkea liukoisten hiilihydraattien pitoisuus (MäLKKI ym., 1978). Liukoisten hiilihydraattien edullinen vaikutus pakkaskuivauksen aromiaineretentioon on havaittu useilla tuotteilla ja myös sipulimehulla suoritetuilla mallikokeilla. (OFCARcik ja Burns, 
1974). Kotimaisella sipulilla havaittu hitaan jäädytyksen edullinen vaikutus aromin säilyvyyteen on myös sopusoinnussa THIJSSENin (1975) selektiivisen diffuusion teorian ja sen perusteella tehtyjen mallikokeiden tulosten kanssa.

Sipulin pakkaskuivauksen kustannuksista VTT:n elintarvikelaboratoriossa tehdyt laskelmat osoittavat, että tähän menetelmään liittyvistä korkeista investointi- ja energiakustannuksista johtuen pelkät pakastus- ja kuivausoperaation kustannukset tulisivat Suomen olosuhteissa olemaan 7 . . 8-kertaiset kuumailmakuivausoperaation nähden. Pakkaskuivatun tukkupakatun valmisteen tuotannon kokonaiskustannukset tulisivat olemaan noin $70 \ldots 80 \%$ korkeammat kuin ilmakuivatulla valmisteella. Kannattavuuden avainkysymyksenä on pakkaskuivausyksikön koko vuotuisen kapasiteetin mahdollisimman tehokas hyväksikäyttö. Koska kannattavasti toimivan yksikön minimikoko on myös jatkuvasti kasvanut, edellyttää tuotannon aloittaminen useiden kuivattavien tuotteiden saamista valmistusohjelmaan.

\section{Tiivistelmä}

Kotimaisella ryväs- ja pistosipulilla suoritettiin vuosina 1973 ja -74 puoliteknillisen mittakaavan pakaskuivauskokeita, joihin oli valittu sipulimateriaali osittain aikaisempien vertailevien tutkimusten perusteella. Tuoreen ja kuivatun sipulin aromin voimakkuus määritettiin kemiallisesti arominmuodostusreaktion eräänä tuotteena syntyvän palorypälehapon määränä sekä veteen lietetyn sipulin hajun kynnysarvona. Palorypälehapon muodostuksen ja kynnysarvon logaritmin välillä havaittiin käänteinen korrelaatio, mutta hajonnan takia lisäsi molempien menetelmien käyttö rinnan määrityksen luotettavuutta. Eräissä tapauksissa arvosteltiin kuivasipulin aromia aistinvaraisilla makuprofiili- ja arvopistemenetelmillä.

Välittömästi korjuun jälkeen suoritettu lyhyt esikuivaus $28^{\circ} \mathrm{C}$ :n lämpötilassa lisäsi ryvässipuli Lemin palorypälehapon muodostusta keskimäärin $18 \%$. Kylmävarastointi vaikutti myös palorypälehapon muodostusta lisäävästi ja muodostus oli 5 kuukauden varastoinnin jälkeen $40 \%$ alkuperäistä korkeammalla tasolla. Tutkittaessa ryväs- ja pistosipulin edullisia pakkaskuivausolosuhteita todettiin molempien soveltuvan hyvin pakkaskuivaukseen. Pakkaskuivaussyklin minimikesto oli $8 \mathrm{~kg} / \mathrm{m}^{2}$ :n kuormituksella 6 tuntia, kun valmisteen vesipitoisuus oli $3,5 \%$. Hitaasti jäädytetty $\left(-20^{\circ} \mathrm{C}\right.$, ilman virtausnopeus $2,3 \mathrm{~m} / \mathrm{s}$ ) sipuli kutistui kuivauksen aikana vähemmän ja kuivavalmiste oli parempilaatuinen kuin nopeampaa jäädytystä käytettäessä.

Kaikki arominmääritysmenetelmät osoittivat kotimaisesta materiaalista pakkaskuivattujen sipulivalmisteiden olevan varsin aromirikkaita kirjallisuustietoihin ja tutkittuihin kaupallisiin valmisteisiin verrattuina. Tällöin edellytettiin kuitenkin, että sipulin pienentäminen suoritettiin välttäen solujen murskaamista. Makuprofiilin perusteella esiintyivät sipulille luonteenomaiset kirpeät ja pistävät (pungent) ja kyynelöitymistä aiheuttavat tekijät (lachrymatory factor) voimakkaina kotimaisissa kuivavalmisteissa.

Palorypälehapporetentio oli ryvässipulin pakkaskuivauksessa keskimäärin $90 \%$ ja pistosipulilla keskimäärin $70 \%$. Ryvässipulin korkea liukoisten hiilihydraattien pitoisuus vaikutti ilmeisesti edullisesti retentioon. Pakkaskuivatun 
ryvässipulin kynnysarvo vaihteli välillä $1,2 \ldots 2,7 \mathrm{mg}$ kuiva-ainetta/1000 $\mathrm{ml}$ ja pistosipulin välillä $0,4 \ldots 0,7 \mathrm{mg}$ kuiva-ainetta $/ 1000 \mathrm{ml}$ kun kirjallisuuden vastaavat arvot vaihtelevat välillä $2,5 \ldots 40 \mathrm{mg}$ kuiva-ainetta/1000 ml. Palorypälehapon muodostus oli sekä ryväs- että pistosipulista pakkaskuivatulla valmisteella noin $45 \mu \mathrm{mol}$ kuiva-ainegrammaa kohti. Ryvässipulin korkea kuiva-aine $(17,5 \ldots 20 \%)$ on varsin edullinen pakkaskuivauksen taloudellisuuden kannalta.

\section{Kiitos}

Aistinarvostelututkimukset on suorittanut fil.maist. Meri Suihko arvosteluryhmineen, josta tekijät esittävät parhaat kiitokset.

\section{KIRJALLISUUSLUETTELO}

Freeman, G. G. \& Whenham, R. J. 1974. Changes in onion (Allium cepa L.) flavour components resulting from some post-harvest processes. J. Sci. Fd Agric. 25: 499-515.

HeINonen, S. 1974. Jäädytys- ja kuivausolosuhteiden vaikutus sipulin pakkaskuivauksessa. 84 p. Dipl. työ, Teknillinen korkeakoulu, Helsinki.

Heiss, R. 1968. Haltbarkeit und Sorptionsverhalten wassarermer Lebensmittel. 163 p. Springer Verlag, Berlin-Heidelberg.

HeNDEL, C. E. \& BAILEY, G. F. 1950. Measurement of nonenzymatic browning of dehydrated vegetables during storage. Fd Technol. 4: 344-347.

JACOBSEN, E. 1975. The FHI-method for moisture determination in cereals and feedstuffs. Cereal Chem. 52: $740-741$.

McСомв, E. A. \& Wright, H. M. 1954. Application of formamide as an extraction solvent with Karl Fischer reagent for the determination of moisture in some food products. Fd Technol. 8: 73-75.

MäLкKı, Y., NıккILÄ, O. E. \& AaLto, M. 1978. Sipulin koostumus ja aromi sekä niihin vaikuttavat tekijät. Maatal.tiet. Aikak. 50: 103-124.

OfCarcik, R. P. \& Burns, E. E. 1974. Carbonyl retention in model systems and Bermuda onion juice during lyophilization. J. Fd Sci. 39: 350-353.

Peleg, Y., Mannheim, C. H. \& Berk, Z. 1970. Changes in quality of dehydrated kibbled onions during storage. J. Fd Sci. 35: 513-517.

SaguY, M., Mannheim, C. H. \& PeLEG, Y. 1970. Estimation of volatile onion aroma and flavour compounds. J. Fd Technol. 5: 165-171.

Schwimmer, S. \& GUAdAGNi, D. G. 1962. Relation between olfactory threshold concentration and pyruvic acid content of onion juice. J. Fd Sci. 27: 94-97.

- - - Venstrom, D. W. \& Guadagni, D. G. 1964. Relation between pyruvate content and odor strength of reconstituted onion powder. Fd Technol. 18: 121-123.

- - \& Weston, W. J. 1961. Enzymatic development of pyruvic acid in onion as a measure of pungency. J. Agr. Fd Chem. 9: 301-304.

Tewari, G. M. \& Bandyopadhyay, C. 1977. Pungency and lachrymatory factor as a measure of flavour strength of onion. Lebensm.-Wiss. u. Technol. 10:94-96.

THJissen, H. A. C. 1975. Effect of process conditions in freeze drying on retention of volatile components. In: Freeze Drying and Advanced Food Technology. Academic Press, London. p. $373-400$.

Käsikirjoitus saapunut 1.3.1978 